\title{
AOR
}

Selected Papers of \#AolR2020:

The $21^{\text {st }}$ Annual Conference of the

Association of Internet Researchers

Virtual Event / 27-31 October 2020

\section{INFORMATION AND COMMUNICATION TECHNOLOGIES (ICTS) AS OPPRESSORS OF SOCIAL MOVEMENTS: A POWER PERSPECTIVE}

\author{
Evronia Azer \\ Coventry University \\ Yingqin Zheng \\ Royal Holloway University of London \\ G. Harindranath \\ Royal Holloway University of London
}

\begin{abstract}
Summary
While the literature discusses ICTs as enablers of activism, this paper stresses the need to look at the holistic context that is dangerous and risky, because of ICTs too. It is a product of 30 semi-structured interviews with grassroots non-hierarchical human rights groups that operated in Egypt before 2015 but no longer do because of oppression and how it affected them physically and psychologically.
\end{abstract}

The value that ICTs have afforded to these groups' organisation and mobilisation is huge, as they have used ICTs to organise their work and disseminate news about human rights violations worldwide. However, this cannot be viewed in isolation from the risk of surveillance and how it affects the groups. The oppression of social movements raises the question of how surveillance makes ICTs work against collective action, and threatens activists' lives (Hier \& Greenberg, 2009; della Porta, 2013; Hosein \& Nyst, 2013). ICTs created even more ways for authoritarian regimes to watch over activists, who rely largely on ICTs to organise their work and communicate. It can be argued that the asymmetry of visibility (Brighenti, 2010) is one result of the advancements in ICTs that directly affected activists' mental health by creating an anxiety among them, not knowing when and how they are being watched. This asymmetry has also endangered activists' lives, because if they are unaware of being under surveillance and take no precautionary measures, they are an easy target for state oppression (Azer et al., 2018, 2019). 
Scholars argue that ICTs can cause growing social change alongside other efforts (McCaughey \& Ayers, 2003). This is no longer true in contexts where ICTs are an arena of power struggle. ICTs are merely a tool that both helps activists, but also helps regimes, even in a more impactful way. The paper shows that the paradoxical nature of ICTs helps analyse activists' modes of visibility and the implicit power in artefacts that enable repressive measures (Azer et al., 2018).

The paradoxes of technology is defined as "a certain technology applied in a certain way in a certain context may have consequences or implications of one kind, and may necessarily and at once be implicated in a contrary set of consequences or implications" (Arnold, 2003, p.231-232). This paper makes a contribution to explain power struggle in ICTs, by applying the paradoxes concept to social movements, and thus analysing tensions and challenges (Zheng et al., 2011) manifested in the online space. The paper shows that the more powerful side is able to make use of ICTs to serve their goals. The two conflicting sides, activists and the state, both make use of ICTs as a space for action and therefore, ICTs have been turned into an arena for power struggle.

Another side of power that this paper discusses is the implicit power that exists within social movements: "even though activists do not want to be in an authoritarian system, they create a situation whereby their refusal to decide who is in charge actually leads to a power hierarchy" (Azer et al., 2019, p.1162). Therefore, the paper contributes to explaining power structures enabled by ICTs inside and outside social movements. It also discusses how the power manifested through ICTs creates much risk of different types for activists (technical, social, psychological and political), who attempt to mitigate the risk, while at the same time work towards their causes, causing a problem in the establishment of trust, and eventually causing collective action to be unsustainable.

\section{Contribution}

This paper brings a much-needed realism to the hype about the role that ICTs can play in collective action, as it shows that aspects of power have been underplayed in the existing literature. This power leads to making movements' collective action unsustainable. More importantly, aspects of power contribute to explaining why the Arab Spring in Egypt "was a success at regime change but a failure at governance" (Bimber, 2017, p.17), and saw a reverse turn on political and human rights, where rights groups have become constantly under attack (Elmasry, 2019).

This contributes to our understanding of activism in risky contexts, but more importantly, it contributes to activists' own understanding of their organisational dynamics. Different civil society groups around the world can benefit from this paper, which shows that collective action does not necessarily unfold in the same ways in various contexts. Due to the large role that authoritarian regimes play, civil society organisations may think how they want to undertake action, not by imitating other groups, but by better understanding the context they operate in. This is particularly important for organisations that may fund civil society organisations in developing countries who struggle for democracy. 
This paper's insights are also important for groups that seek undertaking action based on a horizontal non-hierarchical structure like the groups in this research. Groups in authoritarian contexts may want to better appreciate the severe challenges they may face. It can be dangerous for activists to think that ICTs can be a tool that helps them achieve their goals without thinking of authoritarian use of ICTs, impacts of surveillance and challenges of leadership, and the implications of all these challenges on their mental or physical health. Therefore, the technical activist community can think of how they can design tools and create platforms that are more biased towards serving and protecting activists.

For researchers, journalists and media professionals, this paper also implies that it is important not to be optimistic about movements before waiting to see how they unfold, particularly after oppression remained even stronger than before. As oppression rises, movements struggle and outcomes of uprisings may not always be favourable or similar to each other.

\section{References}

Arnold, M. (2003). On the phenomenology of technology: The "Janus-faces" of mobile phones. Information and Organisation, 13(4), pp.231-256.

Azer, E., Harindranath, G. and Zheng, Y. (2019). Revisiting leadership in information and communication technology (ICT)-enabled activism: A study of Egypt's grassroots human rights groups. New Media \& Society, 21(5), pp.1141-1169.

Azer, E., Zheng, Y. and Harindranath G. (2018). Paradoxes of visibility in activism: The interplay of online power dynamics between activists and the state in the Egyptian revolution. In: Proceedings of the 12th Mediterranean Conference on Information Systems (MCIS). Corfu, Greece, September 2018.

Bimber, B. (2017). Three prompts for collective action in the context of digital media. Political Communication, 34(1), pp.6-20.

Brighenti, A. M. (2010). Visibility in social theory and social research. Hampshire: Palgrave Macmillan.

della Porta, D. (2013). Can democracy be saved? Participation, deliberation and social movements. Chichester: Polity Press.

Elmasry, H. (2019) Why Is Egypt attacking human rights groups? Human Rights Watch. Available at: https://www.hrw.org/news/2019/07/24/why-egypt-attacking-human-rightsgroups (Accessed on 27 July 2019).

Hier, S.P. and Greenberg, J. (2009). Surveillance: power, problems, and politics. Vancouver: UBC Press. 
Hosein, G. and Nyst, C. (2013). Aiding surveillance: An exploration of how development and humanitarian aid initiatives are enabling surveillance in developing countries.

Privacy International. Available at: https://www.privacyinternational.org/sites/default/files/Aiding\%20Surveillance.pdf (Accessed on 22 June 2019).

McCaughey, M. and Ayers, M. D. (2003). Cyberactivism: Online activism in theory and practice. London: Routledge.

Zheng, Y., Venters, W., and Cornford, T. (2011). Collective agility, paradox and organisational improvisation: The development of a particle physics grid. Information Systems Journal, 21(4), pp.303-333. 